Proceedings of the Institution of
Civil Engineers
Municipal Engineer 160
March 2007 Issue MEI
Pages 55-56
Paper 270404
Issue published
Proc. Instn Civ. Engrs Mun. Eng. 159,
Dec. I8I-264

\title{
Discussion: Climate change
}

\section{B. Hanson, Horsham, UK}

In 1996, I edited a paper on 'Personal Transport' published by Architects \& Engineers for Social Responsibility (AESR, recently amalgamated with Scientists for Global Responsibility (SGR)). ${ }^{1}$ With reference to Planning Policy Guidance Note 13-Transport (PPG13), this outlined a national strategy comprising a number of radical land use/transportation initiatives needed to incentivise personal travel choices towards sustainability.

AESR was pleased to note that subsequent planning and transport guidance included some of our recommendations, but the relevant policies have yet to be translated to the built environment in a manner likely to deliver sustainable outcomes. The last decade has been largely wasted as the early advocates of change have waited patiently for mainstream rhetoric to catch up with the global imperatives. During this time the measures taken nationally to reduce travel demands and curb $\mathrm{CO}_{2}$ emissions have been all but negligible. With a few notable exceptions, the planning system is still failing to provide the necessary conditions and the appropriate mix of local land uses for accessibility on foot, cycle or by reliable public transport services.

The predominant patterns of development, mostly market led, have continued to externalise transport infrastructure costs, with sprawling housing estates and large remote retail/business parks forcing almost total car dependency on vast sections of the urban and suburban population. Outside the capital, Government advice on high-density centralised settlements with low parking ratios and car clubs, for example, has gone largely unheeded. In many places small but vocal not-in-my-back-yard, or 'NIMBY', groups have sprung up to resist these more sustainable forms of development, from which local politicians have fled ignominiously.

Consequently the long-term prognosis for the environment is grimmer than ever. Even in London the benefits of the Mayor's Transport Strategy have been woefully inadequate because, in common with the rest of Britain, climate change considerations do not feature highly on the Greater London Authority agenda or that of most London boroughs. Policies focussed mainly on congestion have achieved a $12 \%$ reduction in the emissions of key traffic pollutants within a small congestion charge zone (CCZ). However, when the effects of traffic reassignment and deferred $\mathrm{CO}_{2}$ from 'low-emission' vehicles are taken into account, the net contribution of the London CCZ has barely registered on the target scale of climate change mitigation.
If all we propose to rely on is a 'democratic' society meting out 'encouragement' to responsible behaviour (as John Barrell favours ${ }^{2}$ ), then the cause is already lost and our global fate is sealed. Michael Hebbert suggests that mitigation implies tough regimes to transform travel behaviour. ${ }^{3}$ But until the North Sea is lapping the coast of rural Cambridgeshire, it is inconceivable that these regimes could ever be delivered through the established processes of accountable democracy-and probably not even then. As Barry Simpson rightly observes, public acceptance of global warming will not permit policies that carry significant (personal) costs. ${ }^{4}$

As individuals we simply do not possess the collective instinct (observed in some other species) to do what is in the best interests of the whole community. Human nature, moreover, is characterised by an abhorrence of pre-emptive discomfort, preferring to react only to imminent threats. So, despite warnings from the scientific community, most are conditioned to remain in denial of, or oblivious to, the impending crisis. It is naïve, therefore, to imagine that a majority of voters would ever support radical measures that carry short-term costs and/or disruption to their individual lifestyles, even when threatened by the longer term consequences of collective profligacy.

Regrettably, it follows that the planet cannot be saved by 'politically correct' approaches to consultative democracy involving 'focus groups' or other forms of community engagement. Such forums may work well for delivering traffic calming schemes, home zones and the like, but for restraining personal travel choices or imposing higher costs on car journeys, they are next to useless. As such they will serve only to prolong procrastination and cement political inertia, whence 'business as usual' will continue to hurl us towards a global cataclysm.

The era of politically expedient half-measures came to a close well over a decade ago, but our failure to notice has plunged us in a 'crisis management' situation. If further proof were needed, Shiva Madi Nepal's paper serves to emphasise why radical solutions are now absolutely essential. ${ }^{5}$ His projected growth in travel demands for Kathmandu and, by implication, most other mega-cities of the developing world are potentially catastrophic and environmentally unacceptable.

The 'period of consequence' is already upon us so the established levers of democracy must give way to other forces that are capable of delivering the goods. For the sake of future generations the main political parties have to put aside 
their petty differences and establish a consensus on the essential measures that must be taken to deliver a $60 \%$ reduction in $\mathrm{CO}_{2}$ emissions by 2050, as recommended by the Royal Commission on Environmental Pollution. ${ }^{6}$ Providing no party breaks ranks, the turkeys will be left with few opportunities to vote against Christmas, so a coalition may emerge that is capable of determined political leadership and effective environmental action.

Such a consensus, of course, cannot be confined only to one state, or even to one continent. For humanity to have any hope of averting the worst effects of climatic change, similar high-level political co-operation is needed throughout Europe, North America and the developing world.

Whether we are academics or practitioners, our role as professionals must be to exert the maximum pressure on the decision makers to get real and shape up to their global responsibilities.

\section{REFERENCES}

1. Hanson B. Personal Transport: A Positive Approach to Traffic Reduction. 2003. Available at: http://www.sgc.org.uk/AESR/ AESR_Transport Paper_apro3.pdf.

2. Barrell J. Discussion: Implementing Planning Policy Statement 6, by Simpson B. J. Proceedings of the Institution of Civil Engineers, Municipal Engineer, 2006, 159, No. 4, 257.

3. HeBbert M. Editorial. Proceedings of the Institution of Civil Engineers, Municipal Engineer, 2006, 159, No. 4, 181-182.

4. Simpson B. J. Reducing carbon dioxide emissions from UK road transport. Proceedings of the Institution of Civil Engineers, Municipal Engineer, 2006, 159, No. 4, 203-210.

5. Nepal S. M. Impact of transport policies on energy use and emissions. Proceedings of the Institution of Civil Engineers, Municipal Engineer, 2006, 159, No. 4, 219-229.

6. See Royal Commission on Environmental Pollution. Twentysecond Report. Energy-The Changing Climate. RCEP, London, 2000. 